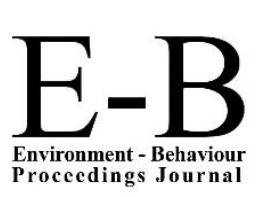

\title{
Securing Proprietary Rights for Buyers of Unascertained Fungible Goods in a Bulk in Malaysia
}

\author{
John Chuah Chong Oon, Azlena Khalid \\ Faculty of Law, \\ Universiti Teknologi MARA, Shah Alam Selangor, Malaysia \\ drjcco@gmail.com, azlena_khalid@hotmail.com \\ Tel of 1 st Author: +6016-2641270
}

\begin{abstract}
The research aims to ascertain the most effective methods to protect the rights of buyers of unascertained fungible goods who have paid under a contract of sale subject to the Malaysian Sale of Goods Act 1957. The research method is doctrinal. The findings reveal that in the event the seller becomes insolvent, the buyer as unsecured creditors would need to compete with the other creditors for the price of the goods. The trust device and the adoption of section 20A and 20B of the English Sale of Goods Act 1979 could provide adequate protection by conferring proprietary rights to buyers.

Keywords: Contract; Sale of unascertained goods; Proprietary rights; Trusts

eISSN: 2398-4287 @ 2020. The Authors. Published for AMER ABRA cE-Bs by e-International Publishing House, Ltd., UK. This is an open access article under the CC BYNC-ND license (http://creativecommons.org/licenses/by-nc-nd/4.0/). Peer-review under responsibility of AMER (Association of Malaysian Environment-Behaviour Researchers), ABRA (Association of Behavioural Researchers on Asians) and cE-Bs (Centre for Environment-Behaviour Studies), Faculty of Architecture, Planning \& Surveying, Universiti Teknologi MARA, Malaysia. DOI: https://doi.org/10.21834/ebpj.v5iSI1.2323
\end{abstract}

\subsection{Introduction}

This article aims to examine the most feasible methods to protect buyers of unascertained fungible goods under a contract of sale subject to the Malaysian Sale of Goods Act 1957 (SOGA 1957). Under section 18 SOGA 1957, no property in the goods passes to the buyer unless the said goods are ascertained. Thus buyers who have paid for their unascertained goods face difficulties if the seller becomes insolvent as the unascertained goods would form part of the seller's assets. Buyers as unsecured creditors would have to compete with the other creditors of the seller for the purchase price and this includes the secured creditors. The researcher argues that the time is ripe for amending SOGA 1957 along the same lines as the English Sale of Goods Act 1979 (SOGA 1979) to protect buyers of unascertained goods. The researcher suggests that such protection in the form of a trust device should be incorporated.

\subsection{Literature Review}

Appropriation of goods under section 23(1) SOGA 1957 entails identifying the subject matter of a contract in a manner whereby the passing of property becomes possible (Worthington, 2000; Atiyah et al., 2005). Debattista (2011) provides that a buyer who has paid the purchase price under a contract of sale of unascertained fungible goods in a bulk but fails to obtain proprietary interest before the delivery of goods, faces problems when the seller is insolvent. The buyer is subject to the proprietary rights of the seller's secured creditors. The researcher submits that such a predicament applies not only in the context of English law, to which Debattista (2011) was referring to, but also applies to Malaysia. Both countries have the same statutory provisions of passing of property when it comes to unascertained fungible goods in a bulk. Section 18 and section 23 of the Malaysian SOGA 1957 are in pari material with section 16 and section 18 Rule 5 of the English Sale of Goods Act 1979 (SOGA 1979) respectively.

The said problem also extends to international trade contracts. Bridge (2002) states that it is common for a buyer of a portion of a bulk of unascertained goods to pay against shipping documents representing the contract quantity and yet cannot obtain proprietary

eISSN: 2398-4287 ( 2020. The Authors. Published for AMER ABRA cE-Bs by e-International Publishing House, Ltd., UK. This is an open access article under the CC BYNC-ND license (http://creativecommons.org/licenses/by-nc-nd/4.0/). Peer-review under responsibility of AMER (Association of Malaysian Environment-Behaviour Researchers), ABRA (Association of Behavioural Researchers on Asians) and cE-Bs (Centre for Environment-Behaviour Studies), Faculty of Architecture, Planning \& Surveying, Universiti Teknologi MARA, Malaysia.

DOI: https://doi.org/10.21834/ebpj.v5iSI1.2323 
interest until the amount contracted for has been separated at the port of unloading. In a FOB ('free on board') contract involving the sale of goods in Malaysia, it was decided in Pemunya Kargo atas Kapal 'Istana VI' v Pemilik Kapal atau Vesel 'Filma Satu' dari Pelabuhan Jakarta Indonesia that the governing law is not solely dictated by the FOB terms but also section 18 SOGA 1957. The court also decided that only the buyer with proprietary rights in the goods purchased can sue the shipowner (carrier of goods) in an action of tort framed in conversion and mis delivery of goods. Further any claims under Section 1 of the Bill of Lading Act 1855 also requires proprietary interest on the part of the claimant. As for a CIF ('cost, insurance, freight') contract for the sale of unascertained goods, section 18 SOGA 1957 may apply where the transfer of goods takes place in Malaysia. Academicians argue that the governing law involving the transfer of movable tangible goods is the law of the country where the property is situated the time of transmission (Lex situs) (Wu, 2005; Debattista, 2011). Likewise, when the parties have chosen the governing law applicable to their contract of sale is Malaysian, the courts will likely give effect to such intention in the absence of any provision in SOGA 1957 to the contrary (Debattista, 2011). The latest law on the creation of trust over an unidentified portion of a bulk of fungible shares emanates from the apex court of Australia. It contradicts the principle of Hunter v Moss (1994). In Ellison \& Sandini Pty Ltd, it was held that the declaration of trust must apply to the whole bulk of fungible shares and not a portion thereof before the need of identification can be negated. Cooper maintains that the whole bulk of shares must be subject to a trust whereby the trustee and beneficiary are equitable owners of their respective shares (Cooper, 2018). However, Australian cases are strictly not binding on the Malaysian courts but only carry persuasive weight.

\subsection{Methods}

A doctrinal method of analysis is employed, which provides an overview of the current law by the arrangement of basic legal concepts, principles and legal rules on decision making (Peters, 2013). It entails the development and study of legal doctrines by traditional methods of statutory and case analysis. The aim is to develop a coherent and rational scheme of legal rules (Schneider \& Teitelbaum, 2006). The primary source of materials consists of statutes and secondary sources of law derived from Malaysia and England. The doctrinal research is not a social science research method that involves field work because this is not a socio-legal research but involves questions of law only that emanates from the courts and statutes. A comparative process between the relevant laws of Malaysia and England will be made to ascertain the various strength and shortcomings of the law on passing of property of unascertained fungible goods in a bulk embodied in SOGA 1957 and SOGA 1979. The research process entails taking the similar provisions of law between the two countries and comparing them to see which laws are more effective in protecting the rights of the buyers of unascertained goods. The principle sections for comparison in this paper is section 20A SOGA 1979 of England and section 2-105(4) Uniform Commercial Code (U.C.C).

\subsection{Findings}

The findings indicate that the two methods of securing proprietary interests for the buyer of unascertained goods are the trust device and amendments to SOGA 1957 by incorporating section 20A and section 20B of the English SOGA 1979. Both methods are thus effective against the seller's creditors who have proprietary interests over the unascertained goods. Firstly, for the creation of a trust, the Malaysian courts have not decided on the requirement of certainty of subject matter in the constitution of a private trust over an unidentified portion of unascertained fungible tangible goods in a bulk. Thus, an amendment in SOGA 1957 should be worded to the effect that there should be nothing to prevent the creation of a trust when an intention to create a trust can be inferred to avoid any conflict between the Malaysian common law and the legislature. Secondly, a more comprehensive solution is to amend SOGA 1957 by implementing the principles embodied in section 20A and 20B of the English SOGA 1979 and section 2-105(4) Uniform Commercial Code (U.C.C). The cumulative effect is an adequate protection for buyers who have paid for the goods despite any constant fluctuation of the seller's bulk of goods.

\subsection{Discussion}

Previous studies have indicated that the methods of protecting pre-paying buyers of unascertained goods against the insolvency of the seller include taking insurance against the risk of loss and estoppel against the seller. Still, they have been aptly criticized as being ineffective (Chua \& Low, 1997). The said methods do not confer proprietary rights on the buyers and are thus ineffective against the seller's creditors who have proprietary interests over the unascertained goods. However, proprietary rights in the goods can pass to buyers if a trust is constituted in favour of them. In Malaysia, the requirement of the three certainties in the creation of trusts as decided in Lee Phek Choo v Ang Guan Yau must be satisfied. Here, the need of certainty of subject matter is the only certainty that may pose a barrier in the creation of a trust.

Under English common law, a private trust may be created over a portion of unascertained fungible tangible goods if a seller expressly declares himself as trustee over the bulk in favour of the buyers. It follows that the buyers then become beneficiaries as tenants in common (Re Stapylton Fletcher Ltd; Re Goldcorp Exchange Ltd (in Receivership). In the absence of an intention to create a trust, the said intention could be inferred from the sale of goods contract, but without an express declaration of trust, any intention to create a trust will not validly constitute a trust (Re London Wine Co. (Shippers) Ltd). The only persuasive authority in Malaysia is the decision of Fawziah Holdings Sdn Bhd, Metramac Corp Sdn Bhd (formerly known as Syarikat Teratai KG Sdn Bhd), which states that the law on the requirement of certainty of subject matter of unascertained fungible tangible goods follows the English common law. Worthington (2000) argues that the equitable title of such goods passes to the buyer who has paid the purchase price in a contract of 
sale of identifiable goods which is specifically enforceable. Under section 58 SOGA 1957, specific performance may be granted to the buyer if the goods in question are specific or ascertained. Thus a sale of unascertained fungible goods does not fall under section 58 SOGA 1957 which therefore negates means any trust device. Worthington's argument applies only to tangible goods under section 52 SOGA 1979. Under section 61 SOGA 1979, the definition of goods covers tangible goods but not intangible property.

The creation of such a trust of over unascertained intangible goods is possible in Malaysia. The definition of goods under section 2 SOGA 1957 is not confined to tangible goods only but also includes intangible goods (see James Capel (Far East) Ltd and YK Fung Securities Sdn Bhd (Tan Koon Swan, Third Party). The question arises whether it is possible for equitable property in unascertained fungible goods to pass to the buyers if the said goods consist of stocks and shares as opposed to tangible goods. Previous studies have cast doubt on the feasibility of establishing a trust in favour of the buyers when there is no express declaration of trust stated in their contracts of sale (Chua \& Low, 1997). Nevertheless, when there is no express declaration of trust, the intention can be inferred from the contract of sale of goods (Re London Wine Co. (Shippers) Ltd). The case of ESPL (M) Sdn. Bhd., Radio \& General Engineering Sdn Bhd decided that there is no uncertainty of subject matter when the proprietor of unascertained fungible shares declared himself as trustee over 50 shares in a bulk of 950 shares. The 50 shares were not identified within the bulk and were held as separate property (Martin, 1996). If the equitable interest of the unidentified 50 shares in the bulk of unascertained shares can pass to the beneficiary, then by reason of analogy, the researcher argues that unascertained fungible shares under a contract of sale need not be identified for property in the shares to pass. Worthington (1996) maintains that contracts for the sale of shares are likely to be specifically enforceable. By applying Hunter v Moss, a sale of unidentified 50 shares from a bulk of 950 fungible shares would confer proprietary interest to a buyer via an enforceable contract provided payment had been made (Worthington, 1996). The requirement of an identifiable bulk is also necessary before the certainty of subject matter is satisfied and takes place in the context of a sale ex-bulk (Re Goldcorp Exchange Ltd (in Receivership). An ex-bulk sale means that the source of goods used by the vendor to satisfy the contract of sale must be identified.

At the High Court in Hunter v Moss (1993), it was held that there is a difference between the transfer of fungible shares as opposed to tangible goods. Such contention can be substantiated by the argument that the main reasoning behind the principle of Hunter $v$ Moss lies with the fungibility of shares (Re CA Pacific Finance). Since the shares are fungible (interchangeable), there is no need to identify which shares are held on trust precisely. In Hunter v Moss, the requirement of certainty of subject matter requires that the shares held on trust must be semantically defined and quantifiable (Wilson, 1998). The researcher submits that the test stated at the lower court of Hunter v Moss should also be adhered to, namely a trust should be validly constituted if the courts can enforce the same. Thus any trust created involving fungible shares can be enforced by the courts. The reasons is because the registration of the legal title of the shares held on trust in for the buyers can take place at a later date. Since the shares in the bulk are interchangeable, it does not matter whether the shares held on trust are identified as trust property during the said registration. Such reasoning is based on the equitable maxim 'equity looks on that as done which ought to be done' (George, 1999). Previous studies suggest that a trust cannot be created over a fungible bulk of fluctuating goods (Chua \& Low, 1997). However, the writers were writing in the context of Singaporean law where under section 61 of its SOGA 1979, the definition of goods only includes tangible property. Common law accepts co-ownership in a bulk of intangibles which is identified and continuously fluctuating (Papaspyrou, 1996). In Lehman Brothers International (Europe) (in administration) and others, Lehman Brothers Finance S.A., it was held that a trust could arise over a fund of constantly fluctuating mass of security interests.

The issue of public policy must also be taken into account. In Re Wait, it was stated that the passing of equitable rights should not contradict with legislation. Sealy (1995) maintains that Atkin LJ in Re Wait was opposed to the fact that in a contract for the sale of goods, any sort of equitable rights could arise in favor of the seller by implication. Hence equitable rights can only come into existence in support of the buyers distinct from the contract for sale subject to the Sale of Goods Act 1893. Such a contention arguably applies to the Malaysian SOGA 1957, which is based on SOGA 1979. Thus for the creation of trust to take place by implication, there must be a statutory provision validating the creation of such a trust. The proposed amendment could cover tangible goods as the definition of goods under section 2 SOGA 1957 includes both tangibles and intangibles. Amending the Malaysian SOGA 1957 along such lines has some support from the Malaysian company law. The effect of the transfer of shares is the inclusion of the name of the transferee into the company's register of members (Section 105(3) Companies Act 2016). Since unascertained fungible shares can be transferred under the said section without the need of identifying the shares subject to the transfer, by reference of analogy, section 18 SOGA 1957 arguably need not be adhered to in a purchase of fungible shares. The researcher submits that shares traded in the central depository which are transferred via book entry under section 148(1) of the Companies Act 2016, are also arguably subject to the same principle. Section 20A SOGA 1979 is to confer buyers of unascertained fungible goods in a bulk proprietary interest in undivided shares as tenants in common. The buyers' shares in the bulk are in proportion to their respective payments. However, the adoption of the English SOGA 1979 should not arguably be confined to merely tangible goods since the definition of goods under section 2 SOGA 1957 includes intangible and tangible goods. Section 20A (1) SOGA 1979 provides that in order for buyers of a specified quantity of unascertained goods to obtain proprietary interest, the 'goods or some of them must form part of a bulk which is identified'. In Malaysia, it is submitted that the requirement of 'a bulk which is identified' under section 20A (1) SOGA 1979 should be modified to cater for initial bulk of goods which could fluctuate. When the bulk fluctuates in a manner that the initial quantity is exceeded, then there are sufficient goods to satisfy the order. However, the fluctuation may result in the amount of the bulk dipping way below the total amount sold to a single buyer. At a later date, the seller may add more goods to the said bulk. To allow such flexibility to the seller, the Malaysian SOGA 1957 should be modified in line with section 2-105(4) U.C.C., which provides that: 'An undivided share in an identified bulk of fungible goods is sufficiently identified to be sold although the quantity of the bulk is not determined.' The critical component in section 2-105(4) U.C.C is 'the quantity of the bulk is not determined' at any time, which allows constant fluctuation of the bulk of goods. The problem of shortfall of goods in the seller's bulk must also be addressed. Each buyer's share in the bulk before any shortfall is determined by the quantity of goods already 
paid for but not yet received (Section 20A (3) SOGA 1979). Under section 20B (1) SOGA 1979, the seller has implied consent to deliver the goods sold to any of the said buyers and no action can be taken against him by the purchases.

In a shortfall of goods, section 20A (4) SOGA 1979 provides that where the aggregate of the undivided shares of the purchases in the bulk falls below the agreed quantity of sale, the entitlement of each buyer shall be reduced in proportion to their purchases. Such an argument seems fair to all buyers as any shrinkage affects them equally. However, the problem arises when the seller has no direct knowledge of any shortfall in the bulk. Worthington $(2000$, p. 86) states that in this situation, the first few buyers would get their full quantity of goods paid for, and the remaining purchases would get a reduced proportion. The loss is thus borne in proportionately value by purchases who take late delivery. While it is true that section 20B (3) SOGA 1979 enables purchases to contract out of section 20B (1) SOGA 1979, it is submitted that not all buyers are aware of such contracting rights. Buyers also may not foresee any shortfall if the seller only discovers the same after the first few deliveries. It is submitted that the Malaysian SOGA 1957 requires a provision to adequately protect buyers of late delivery when there is a shortfall. When the seller becomes insolvent, the buyer is exposed to the credit risk of the seller. When this happens, the said provision becomes essential. The proposed protection could be premised on section 2-502(1) U.C.C. The main principle under the said section is to enable a buyer who has paid and acquired a 'special property' to recover goods from the seller if the seller becomes insolvent within ten days of payment of the purchase price. Though special property here refers to ascertained goods, there is arguably no perceivable harm in applying the same principle to unascertained goods under the Malaysian SOGA 1957. Thus any claim by a buyer against the insolvent seller should rank ahead of the seller's secured creditors if the seller becomes insolvent within ten days of payment of the purchase price. The justification for such contention is that the main thrust of the Malaysian SOGA 1957 is to protect buyers who have paid for their goods but at the same time do not wholly prejudice the seller's creditors by allowing the limit of the ten days grace period.

\subsection{Conclusion and Recommendations}

In conclusion, the requirement of ascertainment under section 18 SOGA 1957 in a sale of unascertained goods causes hardship to buyers who have paid for their goods. Pending ascertainment, property in the said goods remains with the seller. Without a proprietary interest in the goods, the buyer as an unsecured creditor is subject to the rights of the secured creditors of the insolvent seller. The findings indicate that the trust device is a method of securing proprietary interests for the said buyers. Another method is the incorporation of section 20A and 20B SOGA 1979 into Malaysia's SOGA 1957, with some modifications along the lines of U.C.C. to ensure better protection for the buyers. Whichever method is employed, the researcher recommends that the Malaysian legislature amend its SOGA 1957 to protect the rights of buyers of unascertained fungible goods in a bulk.

\section{Acknowledgments}

This research was financed by the Institute of Research Management Innovation (IRMI) University Teknologi MARA (UiTM) Shah Alam, Selangor, Malaysia.

\section{References}

Atiyah, P., Adams, J. N., \& MacQueen, H. (2005). The Sale of Goods. London, UK: Pearson Education Limited.

Bridge, M. (2002). Personal Property Law (3rd ed.). P. Birks (Ed.). New York, US: Oxford University Press Inc.

Chua, B. J., \& Low, K. F. K. (1997). Amendments to the Sale of Goods Act: A Critical Analysis. Singapore Law Review, 18, 172-215.

Cooper, H. (2018). Uncertainty of trust property within a pool of shares. Australian Bar Review, 45, 312.

Debattista, C. (2011). Transfer of Ownership in International Trade (2nd ed.). The Netherlands: Kluwer Law International BV.

Ellison v Sandini Pty Ltd 125 ACSR 249.

ESPL (M) Sdn Bhd v Radio \& General Engineering Sdn Bhd (2005) 2 MLJ 422.

Fawziah Holdings Sdn Bhd v Metramac Corp Sdn Bhd (formerly known as Syarikat Teratai KG Sdn Bhd) (2006) 1 MLJ 505.

George, M. (1999). Malaysian Trust Law. Subang Jaya, Petaling Jaya: Pelanduk Publications (M) Sdn. Bhd.

Hunter v Moss (1993) 1 W.L.R. 934.

Hunter v Moss (1994) 1 W.L.R. 452.

James Capel (Far East) Ltd v YK Fung Securities Sdn. Bhd. (Tan Koon Swan, Third Party) (1996) 2 MLJ 97.

Lee Phek Choo v Ang Guan Yau (1975) 2 MLJ 46.

Lehman Brothers International (Europe) (in administration) \& others v Lehman Brothers Finance S.A. (2011) EWCA Civ 1544 Official Transcript. 
Martin, J. (1996). Certainty of subject matter: A defence of Hunter v. Moss. Conveyancer and Property Lawyer, May/Jun, 223-227.

Papaspyrou, N. (1996). Immobilisation of securities: Part 1 - proprietary rights of indirect holders. Journal of International Banking Law, 11(10), 430-435.

Pemunya Kargo atas Kapal 'Istana VI' v Pemilik Kapal atau Vesel 'Filma Satu' dari Pelabuhan Jakarta Indonesia (2011) 7 MLJ 145.

Peters, A. (2013). Realising utopia as a scholarly endeavor. European Journal of International Law, 24(2), 533-552.

Re CA Pacific Finance (1999) 2 HKC 632.

Re Goldcorp Exchange Ltd (in Receivership) (1995) 1 A.C. 74.

Re London Wine Co. (Shippers) Ltd (1986) P.C.C. 121

Re Stapylton Fletcher Ltd (1994) 1 W.L.R. 1181

Re Wait (1927) 1 Ch. 606.

Schneider, C. E., \& Teitelbaum, L. E. (2006). Life's golden tree: Empirical scholarship and American law. Utah Law Review 53-106.

Sealy, L. (1995). Claims in insolvency to mixed goods. Insolvency Intelligence, 8(3), 17-20.

Wilson, R. (1998). Lord Browne-Wilkinson's "Identifiable Trust Property" principle. Waikato Law Review, 7(6), 87-108.

Worthington, S. (1996). Proprietary Remedies: The nexus between specific performance and constructive trust. Journal of Contract Law, 11, 1-25.

Worthington, S. (2000). Sale of Goods. London, UK: LLP Professional Publishing.

Wu, M. A. (2005). The Malaysian Legal System (3rd ed.). Petaling Jaya: Pearson Malaysia Sdn. Bhd. 